\title{
Literacy Syllabus Evaluation through Needs Analysis of English for Specific Purposes
}

\author{
Nindya Pradanitra Putri*, Ni Luh Ketut Mas Indrawati \\ English Department, Faculty of Arts, Udayana University \\ [pradanitrap@gmail.com], [mas.indrawati@yahoo.com] \\ Denpasar, Bali, Indonesia \\ *Corresponding Author
}

\begin{abstract}
With its unique and progressive approach on education, Green School High School Literacy Syllabus shall be evaluated from an ESP perspective and there is currently no research about it. The aim of this study is to find out what language skills the students think they need and help determine if the existing syllabus at Green School has adequately addressed the needs using qualitative-quantitative methods. Through questionnaires, this study uses Hutchinson-Water's theory of target needs and learning needs. After careful evaluation, the findings suggest that the syllabus has not addressed the Needs sufficiently. Out of 86 subskills, there are only 38 subskills addressed sufficiently. In this context-specific study, there are several implications to be drawn.
\end{abstract}

Keywords: syllabus, English for Specific Purposes, needs analysis.

\begin{abstract}
Abstrak
Dengan pendekatannya yang unik dan progresif dalam pendidikan, silabus Literasi SMA Green School harus dievaluasi dari perspektif ESP (Bahasa Inggris Khusus) dan saat ini belum ada penelitian mengenai hal tersebut. Tujuan penelitian ini ialah untuk mengetahui kemampuan bahasa apa saja yang murid-murid rasa mereka butuhkan guna membantu menentukan apakah silabus yang sudah ada di Green School telah cukup memadai dalam memenuhi kebutuhan dengan metode kualitatif-kuantitatif. Melalui kuisioner, penelitian ini menggunakan teori Hutchinson-Waters mengenai target needs dan learning needs. Setelah penilaian seksama, hasil temuan menunjukkan bahwa silabus yang ada belum memadai dalam memenuhi kebutuhan. Dari 86 sub indikator kemampuan, hanya 36 di antaranya yang terpenuhi. Dalam konteks penelitian spesifik ini, ada beberapa implikasi yang bisa diambil.
\end{abstract}

Kata kunci: silabus, Bahasa Inggris Khusus, analisa kebutuhan.

\section{INTRODUCTION}

The need for English for Specific Purposes (ESP) has been and still is a major concern. An investigation for further information on ESP issues for effective implementation of ESP, especially in Indonesia, shall be conducted. (Sari, 2018) In the 1960s, ESP practitioners believed their main job was to teach the technical vocabulary of a given field or profession. (Smoak, 2003) but it is not. ESP should be seen simply as an 'approach' to teaching or an attitude of mind (Anthony, 1997, p.2) Besides, ESP courses are likely to be designed for adult learners but may be organized for learners at the secondary school level. (Dudley-Evans and St John 
in Javid, Choudhary Zahid, 2013, p. 140) The difference between General English and ESP is the learners' awareness of the needs to learn a language. (Ekici, 2003)

A well-written syllabus could provide a doorway into the pedagogical beliefs of the teacher. (Murphy, 2018, p. 1) But what is a syllabus? It is the description of the contents of the program and the order they will be taught. (Richards \& Schmidt, 2010, p. $139 \& 567)$ To see whether its objectives are being achieved, so that modifications in them can be made if necessary, an evaluation shall be conducted (White, 1971, p. 101) Supporting that idea, in ESP, it is a needs analysis that determines which language skills are most needed by the learners, and the syllabus is designed accordingly. (Rahman, English for Specific Purposes (ESP): A Holistic Review, 2015, p. 1) Needs Analysis (NA) is the systematic collection and analysis of all subjective and objective information necessary to define and validate defensible curriculum purposes that satisfy the language learning requirements of students within the context of particular institutions that influence the learning and teaching situation. (Brown, 1995, pp. 35-36) On that note, an evaluation of the syllabus through Needs Analysis of an ESP course shall be taken as a part of making an appropriate syllabus for an ESP class.

There have been several pieces of research regarding ESP and Needs Analysis. A study was comparing the needs analysis from the students' point of view and employers' regarding English usage at the workplace. (Chen, Chang, \& Chang, 2016) Another work investigated probable mismatch between skills in textbooks and students' perception of the needs. (Zohoorian, 2015) A more recent study investigated students' needs when dealing with and/or using ESP. (Izidi \& Zitouni, 2017)
Having developed their own curriculum, Green School High School has 6-week blocks, with students empowered to make their own choices; it focuses on project-based, experiential, service-learning; and educating for sustainability as their program. Students must acquire 4 credits in English classes (Literacy) to receive the Green School High School Diploma. (Green School, 2018) Literacy is the ability to identify, understand, interpret, create, communicate, and compute, using printed and written materials associated with varying contexts. (UNESCO, 2004, p. 13) The syllabus shall be evaluated from an ESP perspective and there is currently no research about it.

This research employed a theory proposed by Hutchinson and Waters (1987) to evaluate the syllabus of Literacy English for Specific Purposes for High School Grade 3 students at Green School Bali. The central aim of this study is to propose an ESP syllabus which would be effective and appropriate to the students' needs.

In the endeavor to reach its goal, this study has two questions to be explored as follows: What are the students' perceptions of their language skills needs?, How does the existing syllabus at Green School address language skills needs?

This study aims to: find out what language skills the students think they need, help determine if the existing syllabus at Green School adequately addresses the needs.

\section{METHOD}

In order to conduct the research, several aspects must be prepared, and, in this section, the research methods are introduced in four sections.

\section{Data Source}

Data for this research is the existing syllabus of the third grade of high school 
of Green School Bali's English class and questionnaires on students' perceptions of what they think they need and a questionnaire on Literacy instructor' perception of what he thinks the students' need. The current number of students in Grade 3 is 37 , and to achieve $10 \%$ of the population, this study gathered questionnaire responses from 4 student representatives. The questionnaires were conducted through Google Drive. The pilot was conducted from January $30^{\text {th }}$, 2019 to February $6^{\text {th }}, 2019$. After some reviews, the actual questionnaire was then conducted from February $14^{\text {th }}$ through February $28^{\text {th }}$.

\section{Method and Technique of Collecting Data}

Quantitative-qualitative methods are used in this study. Several techniques are used: first, obtaining the current syllabus for High School Literacy, then obtaining the alumni profile, next, piloting of the Student Needs Assessment Questionnaire. After reviewing the result, the next step was conducting a Needs Assessment Questionnaire for both the students and the teacher.

\section{Method and Technique of Analysing Data}

Since this was a mix of qualitative and quantitative study, the steps of analyzing the data were as follows: first, identifying each data type, classifying data into categories, comparing students' perception with the teacher's, then comparing the findings with the existing syllabus, and lastly, giving recommendations if necessary.

\section{Method and Technique of Presenting Data}

This study presents the data taken from the questionnaire and interviews by informal description. Descriptive method was implemented using the following technique: classifying the types of needs based on the four types of language skills, then classifying the types of skills based on Language Needs Skills and Target Needs Skills, and next was giving the analysis based on the data accordingly.

\section{FINDINGS AND DISCUSSIONS}

\section{Students' Perception of Their Language Needs}

a. Reading Language Needs Skills

\begin{tabular}{|c|c|}
\hline Subskill & Points \\
\hline $\begin{array}{l}\text { making inferences about } \\
\text { voice, purpose, values } \\
\text { embedded in a text, and } \\
\text { impact }\end{array}$ & 15 \\
\hline $\begin{array}{l}\text { critically analyzing and } \\
\text { making thematic } \\
\text { connections to the literary } \\
\text { device }\end{array}$ & 17 \\
\hline $\begin{array}{l}\text { make connections between } \\
\text { elements of style, form, and } \\
\text { content }\end{array}$ & 17 \\
\hline $\begin{array}{l}\text { assessing the author's intent } \\
\text { and the reader's } \\
\text { interpretation }\end{array}$ & 18 \\
\hline $\begin{array}{l}\text { self-selecting reading } \\
\text { strategies to improve } \\
\text { comprehension skills }\end{array}$ & 19 \\
\hline
\end{tabular}

Wants for reading for academic needs are self-selecting reading strategies to improve comprehension skills, assessing author's intent and reader's interpretation, critically analyzing and making thematic connections to the literary device, and making connections between elements of style, form, and content. Whereas the Necessities are making inferences about voice, purpose, values embedded in a text, and impact, self-selecting reading strategies to improve comprehension skills, critically 
analyzing and making thematic connections to the literary device, and making connections between elements of style, form, and content.

b. Writing Language Needs Skills

\begin{tabular}{lc}
\hline Subskills & Points \\
\hline $\begin{array}{l}\text { forming critical questions } \\
\text { about voice, purpose, } \\
\text { values embedded in a text, }\end{array}$ \\
and impact \\
forming questions on \\
connections between \\
elements of style, form, \\
and content \\
$\begin{array}{l}\text { taking the risk in style and } \\
\text { structure }\end{array}$ \\
$\begin{array}{l}\text { creatively applying } \\
\text { stylistic structure }\end{array}$ \\
$\begin{array}{l}\text { back up original claims } \\
\text { communicate ideas }\end{array}$ \\
effectively \\
$\begin{array}{l}\text { self-selecting writing } \\
\text { strategies and tools to } \\
\text { improve grammar, } \\
\text { structure, and style } \\
\text { asking critical questions } \\
\text { about language and power }\end{array}$ \\
\hline
\end{tabular}

Wants for writing for academic needs are to communicate ideas effectively, self-selecting writing strategies and tools to improve grammar, structure, and style, asking critical questions about language and power, forming critical questions about voice, purpose, values embedded in a text, and impact, and forming questions on connections between elements of style, form, and content. Whereas all sub-skills are considered Necessities. c. Speaking Language Needs Skills

\begin{tabular}{lc}
\hline Subskills & Points \\
\hline $\begin{array}{l}\text { forming critical questions } \\
\text { about voice, purpose, } \\
\text { values, embedded in a text, } \\
\text { and impact }\end{array}$ & 16 \\
$\begin{array}{l}\text { forming questions on } \\
\text { connections between } \\
\text { elements of style, form, and } \\
\text { content }\end{array}$ & 14 \\
$\begin{array}{l}\text { taking the risk in style and } \\
\text { structure }\end{array}$ & 14 \\
$\begin{array}{l}\text { creatively applying stylistic } \\
\text { structure }\end{array}$ & 16 \\
back up original claims & 15 \\
communicate ideas \\
effectively \\
$\begin{array}{l}\text { asking critical questions } \\
\text { about language and power } \\
\text { engaging in discussions }\end{array}$ \\
$\begin{array}{l}\text { making presentations } \\
\text { criticizing }\end{array}$ \\
\hline
\end{tabular}

Wants of speaking for academic studies are engaging in discussions, communicating ideas effectively, criticizing, forming critical questions about voice, purpose, values embedded in a text, and impact, and lastly creatively applying stylistic structure. The Necessities of speaking for academic studies are backing up original claims, communicating ideas effectively, asking critical questions about language and power, forming critical questions about voice, purpose, values embedded in a text, and impact, forming questions on connections between elements of style, form, and content, engaging in discussions, making presentations, and criticizing. 
d. Listening Language Needs Skills

\begin{tabular}{lc}
\hline \multicolumn{1}{|l}{ Subskills } & \multicolumn{1}{c}{ Points } \\
\hline obtaining gist & 15 \\
$\begin{array}{l}\text { obtaining specific } \\
\text { information }\end{array}$ & 17 \\
$\begin{array}{l}\text { listening for summarizing } \\
\text { recognizing how ideas are }\end{array}$ & 14 \\
represented & 16 \\
$\begin{array}{l}\text { deducing arguments made in } \\
\text { debates }\end{array}$ & 16 \\
$\begin{array}{l}\text { extracting the information } \\
\text { not explicitly stated }\end{array}$ & 15 \\
$\begin{array}{l}\text { recognizing the speaker's } \\
\text { attitude }\end{array}$ & 17 \\
\hline
\end{tabular}

Wants of listening for academic studies are obtaining specific information, recognizing the speaker's attitude, recognizing how ideas are represented, and deducing arguments made in debates. Necessities of listening for academic studies are all seven subskills.

e. Reading Target Needs Skills

\begin{tabular}{lc}
\hline Subskills & Points \\
\hline academic texts & 14 \\
manuals & 12 \\
newspapers & 13 \\
business letters & 13 \\
magazines/periodicals & 10 \\
reports & 14 \\
maps & 17 \\
email messages & 17 \\
brochures & 11
\end{tabular}

$$
\text { dictionary entries }
$$

memos

instruction booklets

legal documents

the agenda of a meeting

the minutes of a meeting

newsletter

catalogs

10

Wants are reading legal documents, reading maps, and reading email messages. All reading sub-skills are regarded as Necessities for target situation.

f. Writing Target Needs Skills

\begin{tabular}{ll}
\hline Subskills & \multicolumn{1}{l}{ Points } \\
\hline business letters & 15 \\
memos & 14 \\
minutes & 14 \\
agendas & 13 \\
notices & 13 \\
email messages & 17 \\
notes & 13 \\
reports & 15 \\
itineraries & 12 \\
commentaries & 11 \\
legal documents & 18 \\
user manuals & 12 \\
brochures & 12 \\
leaflets & 13 \\
\hline
\end{tabular}


Wants are writing legal documents and writing e-mail messages. All writing sub-skills are regarded as Necessities for target situation.

g. Speaking Target Needs Skills

\begin{tabular}{ll}
\hline Subskills & Points \\
\hline with native speakers & 16 \\
with non-native speakers & 16 \\
with teachers/lecturers & 18 \\
with colleagues & 17 \\
with customers/clients & 12 \\
with government officials & 16 \\
in the office & 15 \\
in court & 20 \\
in science labs & 15 \\
at the airports & 16 \\
in transportation contexts & 16 \\
in social settings & 16 \\
\hline
\end{tabular}

Wants for speaking for target situation are speaking in court, speaking with teachers/lecturers, speaking with colleagues, speaking with government officials, speaking at the airport, speaking in transportation contexts, and speaking in social settings. All speaking sub-skills are regarded as Necessities for target situation. h. Listening Target Needs Skills

\begin{tabular}{ll}
\hline Subskills & \multicolumn{1}{l}{ Points } \\
\hline native speakers & 17 \\
non-native speakers & 18 \\
the radio & 14 \\
TV programs & 11 \\
announcements at different & 13 \\
places & \\
films & 13 \\
presentations & 15 \\
meetings & 19 \\
conferences & 19 \\
seminars & 16 \\
discussions & 20 \\
conversations on the phone & 18 \\
face-to-face conversations & 19 \\
\hline
\end{tabular}

Wants for listening for target situation are listening to discussions, listening to meetings, listening to conferences, listening to face-to-face conversations, listening to non-native speakers, listening to conversations on the phone, listening to native speakers, and listening to seminars. All listening sub-skills are regarded as Necessities for target situations. 


\section{How the Curriculum Addresses the Students' Language Needs}

a. Reading Language Needs

\begin{tabular}{|c|c|}
\hline Subskill & Points \\
\hline $\begin{array}{l}\text { making inferences about } \\
\text { voice, purpose, values } \\
\text { embedded in a text, and } \\
\text { impact }\end{array}$ & 14 \\
\hline $\begin{array}{l}\text { critically analyzing and } \\
\text { making thematic connections } \\
\text { to the literary device }\end{array}$ & 11 \\
\hline $\begin{array}{l}\text { make connections between } \\
\text { elements of style, form, and } \\
\text { content }\end{array}$ & 11 \\
\hline $\begin{array}{l}\text { assessing the author's intent } \\
\text { and the reader's interpretation }\end{array}$ & 14 \\
\hline $\begin{array}{l}\text { self-selecting reading } \\
\text { strategies to improve } \\
\text { comprehension skills }\end{array}$ & 14 \\
\hline
\end{tabular}

The students are most proficient in making inferences about voice, purpose, values embedded in a text, and impact, assessing author's intent and reader's interpretation, and self-selecting reading strategies to improve comprehension skills compared to the other two subskills among five of them. After looking at the Wants, the Necessities, and the students' perception of their proficiency, for reading for academic needs, the syllabus has not addressed it sufficiently. The Lacks are critically analyzing and making thematic connections to literary device and making connections between elements of style, form, and content. b. Writing Language Needs

\begin{tabular}{lc}
\hline Subskills & Points \\
\hline $\begin{array}{l}\text { forming critical questions } \\
\text { about voice, purpose, values } \\
\text { embedded in a text, and } \\
\text { impact }\end{array}$ & 15 \\
forming questions on \\
connections between elements \\
of style, form, and content \\
$\begin{array}{l}\text { taking the risk in style and } \\
\text { structure }\end{array}$ \\
$\begin{array}{l}\text { creatively applying stylistic } \\
\text { structure }\end{array}$ \\
$\begin{array}{l}\text { back up original claims } \\
\text { communicate ideas } \\
\text { effectively } \\
\text { self-selecting writing } \\
\text { strategies and tools to } \\
\text { improve grammar, structure, } \\
\text { and style } \\
\text { asking critical questions about } \\
\text { language and power }\end{array}$ \\
\hline
\end{tabular}

The students are most proficient in forming critical questions about voice, purpose, values embedded in a text, and impact. After looking at the Necessities and the students' perception of their proficiency, for writing for academic needs, the syllabus has not addressed it sufficiently yet. The Lacks are forming questions on connection between elements of style, form, and content, taking risk in style and structure, creatively applying stylistic structure, backing up original claims, communicating ideas effectively, selfselecting writing strategies and tools to improve grammar, structure, and style, and lastly, asking critical questions about language and power. 
c. Speaking Language Needs

\begin{tabular}{lc}
\hline Subskills & Points \\
\hline $\begin{array}{l}\text { forming critical questions } \\
\text { about voice, purpose, values, } \\
\text { embedded in a text, and } \\
\text { impact }\end{array}$ & 16 \\
$\begin{array}{l}\text { forming questions on } \\
\text { connections between elements } \\
\text { of style, form, and content }\end{array}$ & 13 \\
$\begin{array}{l}\text { taking the risk in style and } \\
\text { structure }\end{array}$ & 14 \\
$\begin{array}{l}\text { creatively applying stylistic } \\
\text { structure }\end{array}$ & 14 \\
back up original claims & 15 \\
$\begin{array}{l}\text { communicate ideas } \\
\text { effectively } \\
\text { asking critical questions about } \\
\text { language and power }\end{array}$ & 14 \\
engaging in discussions & 16 \\
making presentations & 17 \\
criticizing & 17 \\
\hline
\end{tabular}

The students are most proficient in engaging in discussions. After looking at the Necessities and the students' perception of their proficiency, for speaking for academic needs, the syllabus has not addressed it sufficiently yet. Even though five of the Necessities seemed to be addressed sufficiently, the students have not felt proficient enough in backing up original claims, asking critical questions about language and power, and in forming questions on connections between elements of style, form, and content. The Lacks are then backing up original claims, asking critical questions about language and power, and informing questions on connections between elements of style, form, and content.

d. Listening Language Needs

\begin{tabular}{lc}
\hline Subskills & \multicolumn{1}{c}{ Points } \\
\hline obtaining gist & 18
\end{tabular}

obtaining specific information 16

listening for summarizing $\quad 16$

recognizing how ideas are $\quad 17$ represented

deducing arguments made in $\quad 17$ debates

extracting the information not 17 explicitly stated

recognizing the speaker's attitude

The students are most proficient in engaging in discussions. After looking at the Necessities and

the students' perception of their proficiency, for listening for academic needs, the syllabus has not addressed it sufficiently yet. There is only one Necessity that has not been properly addressed, which is recognizing the speaker's attitude. Lack is then recognizing the speaker's attitude.

e. Reading Target Needs

\begin{tabular}{lc}
\hline \multicolumn{1}{|l}{ Subskills } & \multicolumn{1}{c}{ Points } \\
\hline academic texts & 13 \\
manuals & 14 \\
newspapers & 10 \\
business letters & 11 \\
magazines/periodicals & 11
\end{tabular}




\begin{tabular}{|c|c|}
\hline reports & 13 \\
\hline maps & 14 \\
\hline emaill messages & 14 \\
\hline brochures & 11 \\
\hline dictionary entries & 14 \\
\hline memos & 15 \\
\hline instruction booklets & 10 \\
\hline legal documents & 11 \\
\hline the agenda of a meeting & 10 \\
\hline the minutes of a meeting & 12 \\
\hline newsletter & 13 \\
\hline catalogues & 10 \\
\hline $\begin{array}{l}\text { The students are mos } \\
\text { reading memos. After lo } \\
\text { Necessities and the studen } \\
\text { of their proficiency, for rea } \\
\text { situation, the syllabus has } \\
\text { it sufficiently yet. There } \\
\text { Necessity seemed to } \\
\text { sufficiently, reading } \\
\text { students have not felt prof } \\
\text { in sixteen subskills. Th } \\
\text { reading academic texts, rea } \\
\text { reading newspapers, reac } \\
\text { letters, reading magazin } \\
\text { reading reports, reading } r \\
\text { email messages, readin } \\
\text { reading dictionary entr } \\
\text { instruction booklets, re } \\
\text { documents, reading the } \\
\text { meeting, reading the m } \\
\text { meeting, reading newsle } \\
\text { reading }\end{array}$ & $\begin{array}{l}\text { roficient in } \\
\text { ing at the } \\
\text { perception } \\
\text { g for target } \\
\text { addressed } \\
\text { only one } \\
\text { addressed } \\
\text { nos. The } \\
\text { ent enough } \\
\text { Lacks are } \\
\text { g manuals, } \\
\text { periodicals, } \\
\text { ps, reading } \\
\text { brochures, } \\
\text { ing reading } \\
\text { enda of a } \\
\text { dtes of a } \\
\text { r, and in } \\
\text { catalogues. }\end{array}$ \\
\hline
\end{tabular}

f. Writing Target Needs

\begin{tabular}{ll}
\hline \multicolumn{1}{c}{ Subskills } & \multicolumn{2}{c}{ Points } \\
\hline business letters & 12 \\
memos & 11 \\
minutes & 13 \\
agendas & 10 \\
notices & 12 \\
email messages & 14 \\
notes & 13 \\
reports & 15 \\
itineraries & 9 \\
commentaries & 12 \\
legal documents & 11 \\
user manuals & 12 \\
brochures & 11 \\
leaflets & 12 \\
\hline
\end{tabular}

The students are most proficient in writing reports. After looking at the Necessities and the students' perception of their proficiency, for writing for target situation, the syllabus has not addressed it sufficiently yet. Even though writing reports seemed to be addressed sufficiently, the students have not felt proficient enough in the rest fifteen subskills. The Lacks are writing business letters, writing memos, writing minutes, writing agendas, writing notices, writing email messages, writing notes, writing itineraries, writing commentaries, writing legal documents, writing user manuals, writing brochures, and writing leaflets. 
g. Speaking Target Needs

\begin{tabular}{ll}
\hline \multicolumn{1}{|l}{ Subskills } & \multicolumn{1}{l}{ Points } \\
\hline with native speakers & 16 \\
with non-native speakers & 17 \\
with teachers/lecturers & 18 \\
with colleagues & 17 \\
with customers/clients & 18 \\
with government officials & 13 \\
in the office & 14 \\
in court & 13 \\
in science labs & 13 \\
at the airports & 15 \\
in transportation contexts & 17 \\
in social settings & 17 \\
\hline
\end{tabular}

The students are most proficient in speaking with teachers/lecturers. After looking at the Necessities and the students' perception of their proficiency, for speaking for target situation, the syllabus has not addressed it sufficiently just yet. Even though seven out of twelve Necessities seemed to be addressed already sufficiently, the students have not felt proficient enough in five subskills. The Lacks are then speaking with government officials, speaking in the office, speaking in court, speaking in science labs, and speaking at the airports. h. Listening Target Needs

\begin{tabular}{ll}
\hline \multicolumn{1}{l}{ Subskills } & \multicolumn{1}{l}{ Points } \\
\hline native speakers & 19 \\
non-native speakers & 19 \\
the radio & 17 \\
TV programs & 18 \\
announcements at different & 14 \\
places & \\
films & 16 \\
presentations & 17 \\
meetings & 16 \\
conferences & 18 \\
seminars & 16 \\
discussions & 19 \\
conversations on the phone & 17 \\
face-to-face conversations & 17 \\
\hline
\end{tabular}

The students are equally most proficient in listening to native speakers, listening to non-native speakers, and listening to discussions. After looking at the Necessities and the students' perception of their proficiency, for listening for the target situation, the syllabus has not addressed it sufficiently just yet. Even though there is only one subskill seemed to be not addressed sufficiently. Lack is listening to announcements at different places.

\section{CONCLUSION}

All in all, the findings of the questionnaires suggest that the syllabus has not addressed the Needs sufficiently. Out of 86 subskills, there are only 38 sub-skills addressed sufficiently. The Needs Analysis should have the aim of informing and be able to inform decision- 
making on all other aspects of syllabus development, including the resetting and adjustment of its objectives and aims if needed. While this study is highly context-specific, broader implications can be drawn from it before introducing those related to the immediate context. One implication is the importance of conducting a needs analysis prior to teaching a class. Another implication could be selecting the objectives for a focused set of definite, realistic aims.

\section{REFERENCES}

Anthony, L. (1997, January). English for Specific Purposes: What Does It Mean? Why is It Different? Tokyo, Japan: Waseda University. OnCUE. Vol. 5., No. 3., pp. 9-10

Brown, J. D. (1995). The Elements of Language Curriculum: A Systematic Approach to Program Development. New York: Heinle \& Heinle.

Chen, I.-J., Chang, Y.-H., \& Chang, W.H. (2016). I Learn What I Need: Needs Analysis of English Learning in Taiwan. Universal Journal of Educational Research Vol. 4(1), pp. 1-5. doi:10.13189/ujer.2016.040101

Dudley-Evans and St. John in Javid, Choudhary Zahid. (2013, October). English for Specific Purposes: Its Definition, Characteristics, Scope, and Purpose. European Journal of Scientific Research, Vol. 112(1), pp. 138-151. Retrieved June 2018, from http://www.europeanjournalofscien tificresearch.com/
Ekici, N. (2003). A Needs Assessment Study on English Language Needs of the Tour Guidance Students of Faculty of Applied Sciences at Baskent University: A Case Study. Ankara: Middle East Technical University.

Green School Bali. (2018, November 21). About. Retrieved from Green School:

https://www.greenschool.org/about/

Hutchinson, T., \& Waters, A. (1984). English for Specific Purposes: A Learning- Centred Approach. Cambridge: Cambridge University Press.

Izidi, R., \& Zitouni, M. (2017, June). ESP Needs Analysis: the Case of Mechanical Engineering Students at the University of Sciences and Technology, Oran U.S.T.O. Revue des Etudes Humaines et sociales B/Littérature et Philosophie No. 18, pp. 16-25. DOI: 10.33858/0500000-018-054

Murphy, R. S. (2018). The Concept of Syllabus Design and Curriculum Development: A Look at Five Major Syllabus Designs. In A. Faravani, M. Zeraatpishe, M. Azarnoosh, \& H. R. Kargozari (Eds.), Issues in Syllabus Design (Vol. 6, p. 1). Rotterdam.

Rahman, M. (2015). English for Specific Purposes (ESP): A Holistic Review. Universal Journal of Educational Research Vol. 3.1, pp. 24-31. DOI: 10.13189/ujer.2015.030104

Richards, J. C., \& Schmidt, R. (2010). Longman Dictionary of Language 
Teaching and Applied Linguistics. New York: Pearson Education.

Sari, Farnia. (2019, July). The Issues of ESP Instruction for University Level in Indonesia. Global Expert Jurnal Bahasa dan Sastra, Vol. 7 (1), pp. 1-6

Smoak, R. (2003, April). What is English for Specific Purposes? English Teaching Forum, Vol. 41 (2), pp. 22-27.

UNESCO. (2004). The Plurality of Literacy and its Implications for Policies and Programmes: Position Paper. Paris: United Nations Educational, Scientific and Cultural Organization.

White, J. P. (1971). The Concept of Curriculum Evaluation. Journal of Curriculum Studies, Vol. 3 (2), pp. 101-112.

DOI: $10.1080 / 0022027710030202$

Zohoorian, Z. (2015, January). A Needs Analysis Approach: An Investigation of Needs in an EAP Context. Theory and Practice in Language Studies, Vol. 5(1), pp. 58-65. Retrieved May 12, 2018 